\title{
Determining the body condition of short-tailed shearwaters: implications for migratory flight ranges and starvation events
}

\author{
C. L. Baduini ${ }^{1, *}$, J. R. Lovvorn ${ }^{2}$, G. L. Hunt Jr ${ }^{1}$ \\ ${ }^{1}$ Department of Ecology and Evolutionary Biology, University of California, Irvine, California 92697, USA \\ ${ }^{2}$ Department of Zoology, University of Wyoming, Laramie, Wyoming 82071, USA
}

\begin{abstract}
Short-tailed shearwaters Puffinus tenuirostris migrate annually from breeding areas in southeast Australia and Tasmania to the Bering Sea to feed on abundant prey aggregations, mainly euphausiids. Occasionally thousands of shearwaters die of starvation en route, within, or on return from the Bering Sea. Collection of live and dead shearwaters in the southeastern Bering Sea in 1997 , 1998, and 1999 allowed us to measure seasonal changes in energy reserves during a major mortality event. As birds lost body mass, lipid mass initially decreased faster than that of pectoralis muscle, but loss of pectoralis mass increased markedly at a body mass around $500 \mathrm{~g}$ when lipids were almost depleted ( 33 g remaining). Death occurred as body mass approached $426 \mathrm{~g}$. Individuals near this body mass had lipid values permitting estimated flight ranges of 140 to $400 \mathrm{~km}$, a range less than that potentially covered in $1 \mathrm{~d}$ by shearwaters searching for prey (440 to $1124 \mathrm{~km} \mathrm{~d}^{-1}$ ). Seasonal differences in body composition were most striking among body and bone marrow lipid contents, with the lowest values occurring during the die-off in fall 1997 and in fall 1998. The lack of shearwater mortality in fall 1998 may have resulted from more consistent winds that decreased flight costs and from greater availability of alternative fish prey. Our data allow estimates of usable energy stores and flight ranges based on lipid reserves in short-tailed shearwaters. Estimated flight ranges suggest that if feeding conditions are poor near Japan or near other termination points of the transequatorial migration routes shearwaters may have few reserves available to support foraging for food and starvation events may occur. Our findings suggest how their energetic strategies and migration are shaped by seasonal and annual variability of prey during transglobal movements of short-tailed shearwaters between oceanic regions.
\end{abstract}

KEY WORDS: Bering Sea $\cdot$ Body condition $\cdot$ Lipid metabolism $\cdot$ Nutritional stress $\cdot$ Starvation $\cdot$ Flight range $\cdot$ Puffinus tenuirostris $\cdot$ Short-tailed shearwater

\section{INTRODUCTION}

Most of the world's 23 million short-tailed shearwaters Puffinus tenuirostris complete an annual $15000 \mathrm{~km}$ migration from breeding grounds in southeast Australia and Tasmania to feed in the North Pacific Ocean and Bering Sea during June through September (Ser-

${ }^{*}$ Present address: Joint Science Department, The Claremont Colleges, Claremont, California 91711, USA.

E-mail: cbaduini@jsd.claremont.edu venty 1958, Shuntov 1974, Hunt et al. 1981, Skira 1986). Although this foraging strategy most likely evolved to utilize the timing in peak availability of prey resources, which alternates seasonally between the northern and southern hemispheres, shearwaters occasionally starve by the thousands while adhering to this strategy (Douglas \& Setton 1955, Serventy 1967, Oka \& Maruyama 1986). While short-tailed shearwaters were being studied along the inner frontal region of the southeastern Bering Sea in 1997, a large-scale mortality event occurred (July to September; Baduini et al. 
2001). Large scale die-offs of shearwaters are infrequent in the Bering Sea because this is a highly productive area, with $\mathrm{C}$ fixation of $\sim 200 \mathrm{mg} \mathrm{m}^{-2} \mathrm{yr}^{-1}$ on the shelf (McRoy et al. 1986) and usually has abundant prey resources of euphausiids and fish. The objective of this study was to describe the patterns of loss of body mass, lipids, protein, and bone marrow lipids in a natural population of short-tailed shearwaters before, during, and after this mass mortality event. Additionally we modeled the flight ranges potentially available to birds given their remaining lipid reserves. The results provide a context for assessing the energetic requirements and flight limitations for individuals searching large areas (several hundred $\mathrm{km}^{2}$ ) for patchily distributed prey in the Bering Sea, for adult foraging trips during breeding, and for shearwaters migrating across productive and non-productive oceanic regions.

Few studies of birds have been able to show severe nutritional stress in a natural setting (Owen \& Cook 1977, Jenni-Eiermann \& Schifferli 1989, Fournier \& Hines 1994, Jeske et al. 1994, Lovvorn 1994), and few have determined the relation between lipid and protein mobilization during starvation. The observed dieoff of short-tailed shearwaters in the southeastern Bering Sea in 1997 was unusual not only for its magnitude of $\sim 200000$ individuals and up to $11 \%$ of the total population (live and dead shearwaters surveyed during fall 1997) but also for its timing and location (Baduini et al. 2001). Most major mortality events of short-tailed shearwaters occurred where the transequatorial migrations terminate. In the southern hemisphere, die-offs occur along the eastern coast of Australia on the return trip from the North Pacific Ocean (Douglas \& Setton 1955, Serventy 1967). In the northern hemisphere, die-offs have occurred along the Pacific coast of Japan in April through June (Kawaguchi \& Marumo 1964, Ozawa 1964, Kuroda 1967, Sugimori et al. 1976, Oka \& Maruyama 1986, Toyohashi Wild Bird Club unpubl. data). These repeated mortality events off Japan and Australia have been associated mostly with young-of-the-year individuals caught in storms, a lack of food, and subsequent starvation, and little evidence exists for death caused by disease (Serventy 1967). Thus, it is possible to conceive how useable energetic stores become critical to traveling long distances between productive oceanic regions where these birds must feed and renew energy reserves.

To determine usable levels of stored reserves, we described the components of body composition (lipids versus lean components) that were utilized initially as short-tailed shearwaters began to starve. Starving birds and mammals adjust to long-term fasting and starvation generally by using fat reserves and sparing protein (Cherel et al. 1988, 1992, Robin et al. 1988,
Groscolas et al. 1991, Cherel et al. 1993, 1995). Bone marrow lipid, which contains mainly fat cells (Little 1973), is usually one of the last lipid reserves utilized during starvation (Pond 1978). As a result, the absence of bone marrow lipid has been used to indicate severe fasting conditions in birds (Raveling et al. 1978, Hutchinson \& Owen 1984, Jeske et al. 1994, Thouzeau et al. 1997) and mammals (Davis et al. 1987, La Jeunesse \& Peterson 1993, Chan-McLeod et al. 1995). Also, Oka \& Maruyama (1985) have used visual evaluation of tibiotarsus and femur marrows as a method of estimating nutritional condition of short-tailed shearwaters during mortality events in Japanese waters. Thus, we examined bone marrow lipid levels in order to identify severe starvation.

We also modeled how observed variation in body condition affects flight ranges, because short-tailed shearwaters are highly migratory and much of their foraging success depends on searching large expanses of ocean and locating highly variable and aggregated prey. On the basis of measured and predicted body lipid stores, we estimated flight ranges of shearwaters in the Bering Sea of adults performing long and short foraging trips to provision chicks at colonies in Australia (Weimerskirch \& Cherel 1998), and adults leaving breeding colonies to begin the transequatorial migration to the North Pacific Ocean (Lill \& Baldwin 1983). Our results suggest how the long migrations, energetic strategies, and mortality patterns of these shearwaters are shaped by seasonal and inter-annual fluctuations in the timing and location of oceanic production at global scales.

\section{MATERIALS AND METHODS}

Changes in body composition with starvation. Shorttailed shearwaters were collected under permit during 6 research cruises to the southeastern Bering Sea in spring (27 May to 28 June) and fall (27 August to 12 September) 1997, during spring (23 May to 24 June) and fall (15 August to 7 September) 1998, and in spring (17 May to 19 June) and summer (19 July to 22 August) 1999

Table 1. Summary of number of individual short-tailed shearwaters collected in this study from the southeastern Bering Sea.

\begin{tabular}{|cccc|}
\hline Year & $\begin{array}{c}\text { Spring } \\
\text { (May/June) }\end{array}$ & $\begin{array}{c}\text { Summer } \\
\text { (July/August) }\end{array}$ & $\begin{array}{c}\text { Fall } \\
\text { (August/September) }\end{array}$ \\
\hline 1997 & 36 & 0 & $57^{\mathrm{a}}$ \\
1998 & 36 & 0 & 41 \\
1999 & 59 & 45 & 0 \\
ancludes beachcast carcasses collected during the mortality \\
event for analyses
\end{tabular}


(Table 1 \& Fig. 1). Shearwaters foraging or sitting on the water were collected using a 12 gauge shotgun. In addition, during the mortality event of fall 1997, we obtained 12 'fresh' beachcast carcasses with feathers still waterproof, indicating that death had probably occurred within 1 wk of collection (31 July to 17 Aug 1997; carcasses provided by the US Fish and Wildlife Service, Anchorage, AK). Although it is uncommon to sample body condition of dead individuals, because these carcasses were fresh and internal organs were intact, they provided a unique opportunity to determine the body mass, lipid content, and pectoralis muscle mass from recently dead birds. Every measurement was not made on each individual. The distribution of measurements made on specimens varied among years and between collected and beachcast individuals (Table 2). Because not all measures were available for all birds sampled, sample sizes in the analyses dif-

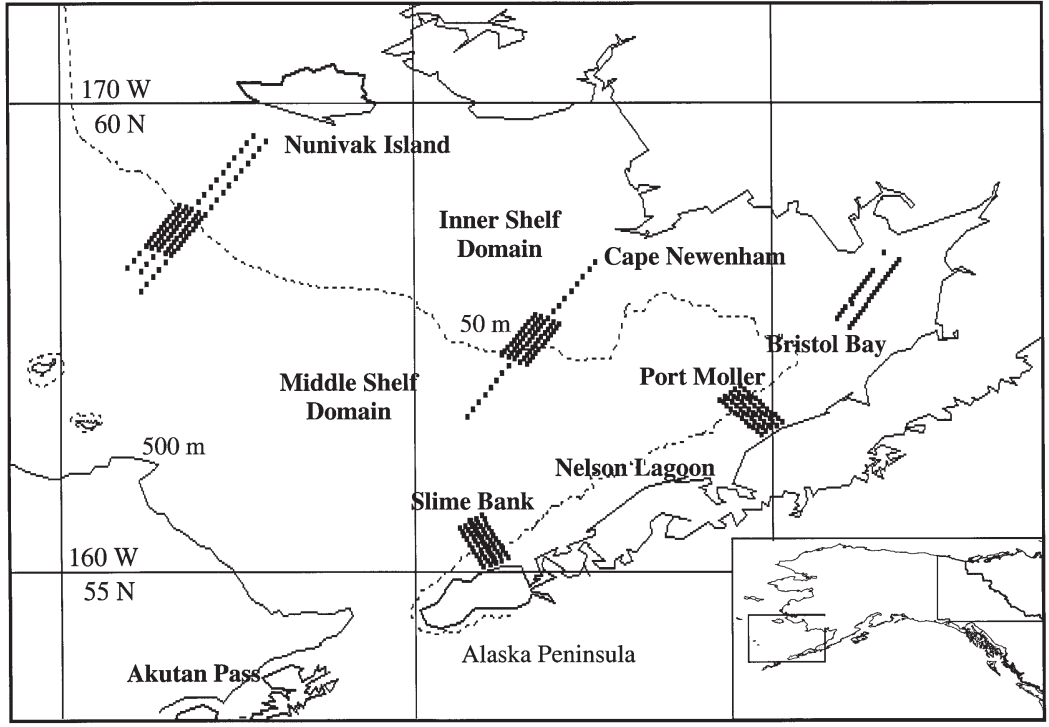

Fig. 1. The study area in the southeastern Bering Sea. (ø) stations within the Nunivak Island, Cape Newenham, Bristol Bay, Port Moller, Nelson Lagoon, and Slime Bank grids. The inner shelf domain is inside of the $50 \mathrm{~m}$ isobath, the middle domain between the 50 and $100 \mathrm{~m}$ isobaths, and the outer domain between the 100 and $200 \mathrm{~m}$ isobaths fer from the numbers of birds collected.

Wet body mass (total mass upon capture minus stomach contents) was measured at sea immediately after collection using a $1 \mathrm{~kg}$ scale $( \pm 10 \mathrm{~g}$; Pesola AG, Switzerland). Wet breast muscle mass (1 side of pectoralis muscle) was measured using a top-loading precision balance $( \pm 0.01 \mathrm{~g}$; Acculab Sartorius Group, Newtown, PA). Wet pectoralis mass measurements were doubled for analyses (i.e. full breast). Wet liver masses were measured at sea using a Pesola $200 \mathrm{~g}$ scale $( \pm 2 \mathrm{~g})$. All organs were returned to the carcass and carcasses were then frozen and stored $\left(-20^{\circ} \mathrm{C}\right)$ for later analyses (i.e. homogenization for lipid extraction).

Frozen birds were thawed and defeathered by hand plucking. The entire bird (excluding feathers) was passed through a conventional meat grinder 6 times (2 times through a wide bore blade and 4 times through a small bore blade), with hand mixing between passes to homogenize the sample. Three subsamples of $30 \mathrm{~g}$ (wet mass) were measured from the homogenate, and each was combined with 2 to $3 \mathrm{~g}$ of infusorial earth that was dried and weighed before addition to the homogenate. The combined sample was dried in a convection oven at $60^{\circ} \mathrm{C}\left( \pm 5^{\circ}\right.$; Kerr 1982) for 24 to $48 \mathrm{~h}$ or until the dry mass stabilized. Dry body mass was determined by multiplying the mean percentage dry content of homogenized subsamples by wet body mass (without stomach contents). Lean dry mass was then calculated by subtracting dry body lipid mass (in grams) from dry body mass (excluding feathers).

Dry samples were placed in tared extraction thimbles and weighed. Lipid content was obtained by extracting

Table 2. Summary of body measurements taken on short-tailed shearwaters collected alive and beachcast during each season (by number of individuals)

\begin{tabular}{|c|c|c|c|c|c|c|c|c|}
\hline \multirow[t]{2}{*}{ Measurement } & \multicolumn{6}{|c|}{ Collected alive } & \multirow{2}{*}{$\begin{array}{c}\text { Beachcast } \\
1997 \\
\text { Fall }\end{array}$} & \multirow[t]{2}{*}{ Total } \\
\hline & Spring & Fall & Spring & Fall & Spring & Summer & & \\
\hline Wet body mass & 36 & 45 & 36 & 41 & 59 & 45 & 12 & 274 \\
\hline Lean dry mass & 24 & 22 & 24 & 23 & 24 & 22 & 12 & 151 \\
\hline Dry lipid content & 24 & 22 & 24 & 23 & 24 & 22 & 12 & 151 \\
\hline Wet pectoralis mass & 10 & 39 & 36 & 41 & 59 & 44 & 12 & 241 \\
\hline Wet liver mass & 0 & 0 & 35 & 41 & 58 & 45 & 12 & 191 \\
\hline Bone marrow lipid mass & 11 & 15 & 0 & 7 & 0 & 0 & 0 & 33 \\
\hline
\end{tabular}


the dried samples in petroleum ether (boiling range 39.3 to $56.5^{\circ} \mathrm{C}$ ) for $20 \pm 1 \mathrm{~h}$ (Christie 1982, Dobush et al. 1985, Roby 1991). After extraction, samples were redried in a convection oven for $24 \mathrm{~h}$ or until a constant mass was achieved. The lipid content of each subsample was determined as the difference in dry mass of the sample before and after extraction (excluding mass of infusorial earth). The mean lipid content in the 3 subsamples was used to calculate body lipids of the entire individual. Body fat (in grams) was calculated by multiplying the mean percentage lipid content of the subsamples by dry body mass (excluding feathers).

Bone marrow lipid content was measured in a separate set of birds $(\mathrm{n}=26)$ collected in June and August 1997 and from 7 birds collected in August 1998, which were not processed for body lipid content. Lipids were measured and combined from 3 leg bones (femur, tibiotarsus, and tarsometatarsus). For each bird, both legs were dissected, muscle and connective tissue were scraped from bones, and each leg was used as a dependent replicate. Next, the leg bones were broken in half to expose marrow for extraction. All 3 leg bones were combined and dried to constant mass in an oven at $60^{\circ} \mathrm{C}$, weighed on a top-loading AE240 precision balance (Mettler Toledo, Columbus, $\mathrm{OH}$ ), and extracted in petroleum ether for $20 \mathrm{~h}$. Extracted bones were redried for $24 \mathrm{~h}$ and reweighed. Lipid content was estimated as the difference in leg bone mass before and after extraction. If the leg bones were broken during the at-sea collection, they were not used for lipid analyses.

To investigate patterns of lipid and protein loss during starvation, regressions were constructed for lipid content, wet pectoralis muscle mass (full breast), and wet liver mass on wet body mass. Although only a single value was measured for each body component for each bird, collectively, the many samples of birds over a $3 \mathrm{yr}$ period revealed patterns that may have occurred as a single bird starved in the wild. This method, although not as rigorous as experimentally starving individuals in a controlled environment, had the advantage of allowing observation of patterns in a natural setting.

Total body length was used as an overall measure of body size to determine whether body size, rather than emaciation, could be a major contributor to the patterns observed in body composition. The first principal component in a principal component analysis of 5 measures of body size (total length, tarsus length, culmen, wing chord, and bill depth) accounted for $27 \%$ of the variance in body size. We used total length as an overall measure of body size because it had the highest factor loading (0.432) of the 5 measures with the first principal component and was available for all birds. ANOVA showed that total lengths of males, females, and individuals of unknown sex did not differ signifi- cantly from one another $(F=1.73, \mathrm{p}=0.180, \mathrm{n}=260)$. There was also no significant difference in total length between mature and immature individuals $(F=0.063$, $\mathrm{p}=0.802, \mathrm{n}=148$ ). Mature individuals were identified as females only by the presence of a convoluted oviduct, indicating that the bird had experienced egg laying. Thus, although the sample contained some smaller and some larger birds, on average, all individuals from our sample population were of similar size in terms of total length. Therefore, the patterns in body mass, lipid content, and muscle mass loss could be analyzed independently of body size.

Since lipid mass, pectoralis mass, and liver mass are components of body mass, it is statistically inappropriate to regress body mass with lipid mass, etc., because the $x$ and $y$ variables are not independent of one another and by necessity would be correlated (van der Meer \& Piersma 1994). Thus, dry lipid mass was regressed with lean dry body mass, an independent measure. Wet body mass is a universal component used by both researchers and managers for describing relative body condition of birds. Thus, body mass was related to changes in lipids and other body components. To relate the amount of lipid stores remaining at a given wet body mass, we included isoclines of wet body mass in Fig. 2. Wet pectoralis mass was regressed against dry lipid mass to indicate the relative use of lipid storage components and protein during starvation.

Linear $(y=m x+b)$, power $\left(y=m x^{a}\right)$, and exponential $\left(y=m e^{a x}\right)$ functions were tested for best fit with each data set (best fit $=$ highest $r^{2}$ value; Statistica for Windows version 5, Statsoft Inc., Tulsa, OK). The inflection point of the function (where the change in lean dry mass and change in lipid mass were equal and slope = 1) was used to determine the body mass at which transition occurred from use of primarily lipid to mostly muscle stores.

Comparisons of body condition among seasons. To compare body condition indices among seasons and years, we tested for the covariance of condition variables with total length (Packard \& Boardman 1987). When significant, a covariance adjusted mean was calculated using Statistica 95 to determine seasonal differences in lipid content, pectoralis mass, liver mass, and bone marrow lipid content.

Estimation of flight ranges. Body lipid values predicted for individuals of varying wet body mass were used to calculate the energy available for flight and corresponding flight ranges of shearwaters using Pennycuick's (1989) 'flight.bas' program. The program calculated the costs of flight by using the power required to maintain flapping flight at the maximum range speed and was uncorrected for wind speed. Flight distance for an individual with given lipid content was calculated assuming an energy density of $3.9 \times 10^{7} \mathrm{~J} \mathrm{~kg}^{-1}$ of 
(a)

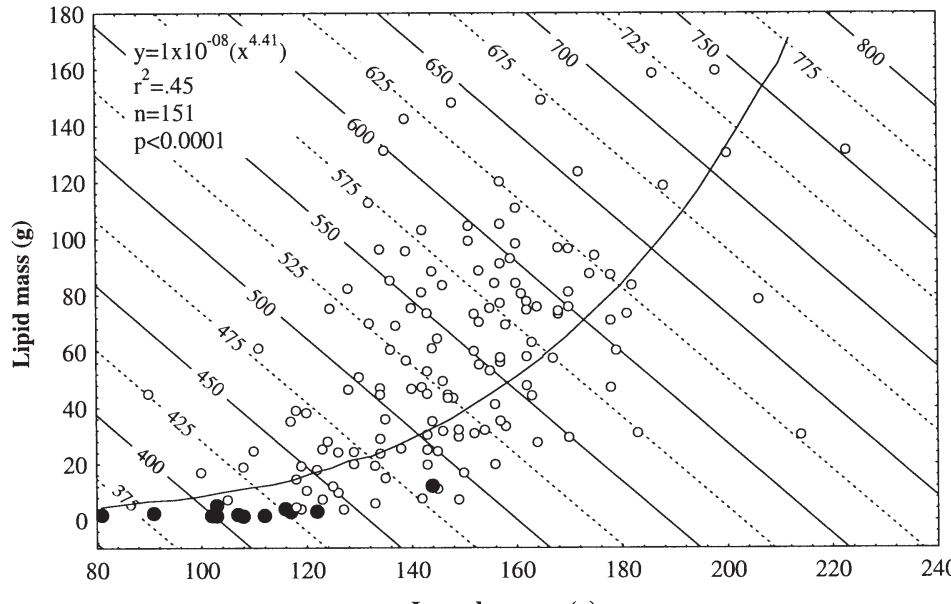

Live birds $\circ$

(b)

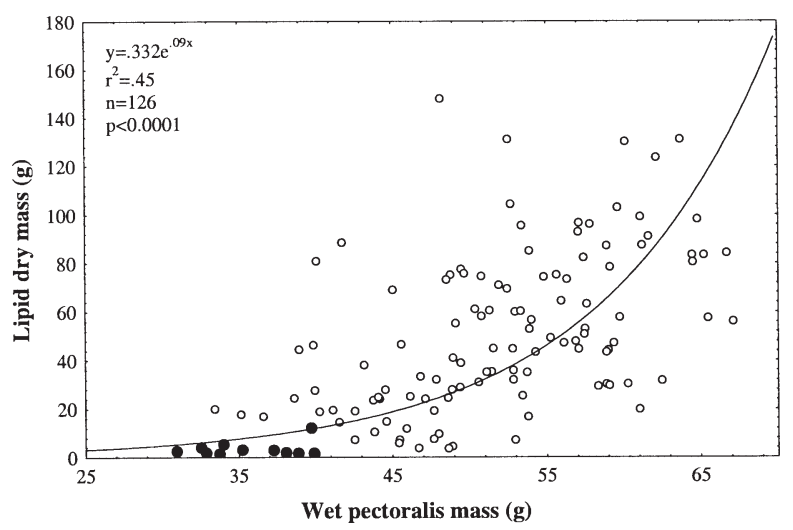

(c)

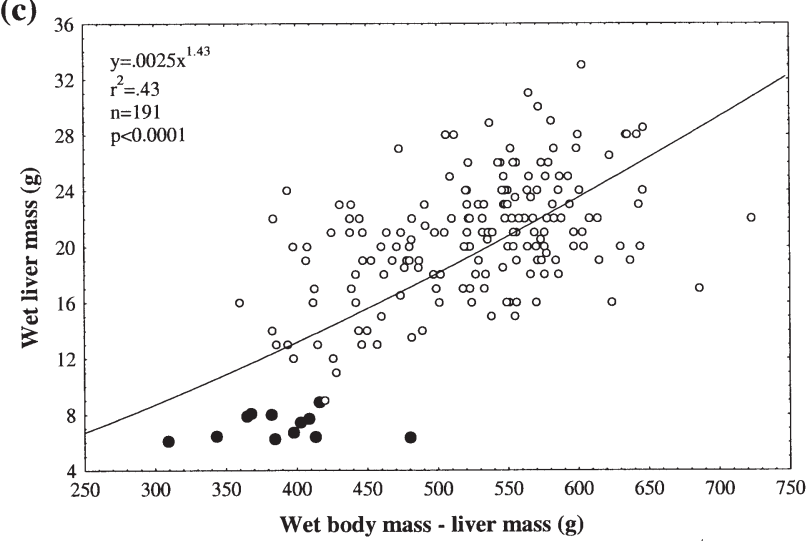

Fig. 2. Significant regression equations for patterns of nutritional condition in short-tailed shearwaters. (a) Change in lean dry mass with lipid mass. Isoclines are values for body mass (wet body mass upon capture minus stomach contents). The breakpoint in the regression is at $8 \mathrm{~g}$ lipid mass and corresponds to a body mass of $450 \mathrm{~g}$. (b) Change in pectoralis muscle mass with lipid mass. (c) Change in wet body mass minus liver mass and in liver mass

fat and assuming that fat was the only energy source (Pennycuick 1989). Lipid reserves for a given wet body mass were estimated from the regression equation in Fig. 2.

We used lipid stores to estimate flight ranges for short-tailed shearwaters; however, there is evidence that shorebirds and passerines also utilize protein stores while migrating (Piersma \& Jukema 1990, JenniEiermann \& Jenni 1991, Akesson et al. 1992, Gauthier et al. 1992). Nevertheless, it is unclear whether the use of protein stores during migration is devoted directly to increased flight costs, thus allowing an increase in flight range. Lindstrom \& Piersma (1993) have suggested that protein utilization during migration may be attributed to tissue maintenance (as opposed to flight per se) during the increased demands of flight. Additionally, there is empirical evidence that the relative contribution of protein relative to total energy expenditure during sustained flight varies according to initial lipid stores (Jenni \& Jenni-Eiermann 1999). When ini- tial fat content of migrating birds is low (5\% of total body mass), the relative protein contribution to total energy expenditure is up to $20 \%$. When initial fat content is greater ( 25 to $30 \%$ ), relative protein contribution to total energy expenditure is ca 5 to $7 \%$ and this value remains relatively constant for birds with a fat content $>30 \%$. In our flight calculation estimates, we calculated flight ranges for seabirds with a range of fat estimates from 2 to $25 \%$ and thus the contribution of protein catabolism during migration may change according to fat content. Thus, our estimates of flight range are minimum estimates and do not include the contribution of proteins to estimated flight distance. It is likely that because of the low energy density of protein stores (ca $4.1 \mathrm{kcal} \mathrm{g}^{-1}$ ) relative to lipid stores (ca $9.3 \mathrm{kcal} \mathrm{g}^{-1}$ ), the contribution of proteins to energy expenditure and increased distance in flight is much less than that of lipids. In a review of fat and protein utilization during long migratory flight distances, Jenni \& Jenni-Eiermann (1999) concluded that during migra- 
tion, endurance flight is sustained mostly (up to 90\%) by lipid fuel stores if dehydration is negligible.

Because shearwaters do not fly solely by flapping, but use a combination of flapping and gliding (Warham 1990), we developed a range of distance estimates that may account for the differences in costs between these modes of flight (Ballance 1995). Furness \& Bryant (1996) measured costs of flight in relation to wind speed in the northern fulmar Fulmarus glacialis, a procellariiform seabird, slightly larger than shearwaters, using the doubly labeled water technique (Tatner \& Bryant 1989). Wingbeat rate (beats $\mathrm{s}^{-1}$ ) and field metabolic rates estimated for flight gradually decreased as a function of wind speed and leveled out at 2 to 3 times the basal metabolic rate (BMR) when wind speeds reached $8 \mathrm{~m} \mathrm{~s}^{-1}$ and wingbeat rate was $<1$ beat $\mathrm{s}^{-1}$, essentially gliding flight. The mean at-sea (flying) metabolic rate was 4.5 times BMR, but ranged between 1.4 and 7.8 times BMR depending on wind conditions. They concluded that for individual birds with high field metabolic rates, flapping flight was used for up to half the time spent at sea. The flight.bas program, based on aerodynamic theory, determined that the power required for continuous flapping flight of short-tailed shearwaters of varying wet body mass ranged from 10.3 to 19.0 times BMR, approximately double the estimates measured by Furness \& Bryant (1996). Because of the variable range in flight costs, we calculated flight ranges based on proportions between flapping and gliding flight (from 0 to $100 \%$ gliding flight). Flight ranges calculated by the equations of aerodynamic theory for flapping flight using the flight.bas program (Pennycuick 1989) correspond to estimates for $100 \%$ flapping flight. These distance values were then adjusted according to the percentage of time spent gliding (for example, for $50 \%$ flapping and 50\% gliding flight, estimated flight range was doubled). Also, a maximum possible range that shearwaters could fly is provided, given that short-tailed shearwaters were solely using gliding flight. Ballance (1995) showed, using doubly-labeled water measurements on free-ranging redfooted boobies Sula tridactyla, that flight costs may be as much as a third less than costs estimated if steady flapping flight were assumed (Pennycuick 1989). The discrepancy is probably related to the dynamic soaring type of flight used by red-footed boobies (Ballance 1995).

\section{RESULTS}

\section{Changes in body composition with starvation}

Lipid mass decreased significantly with decreasing lean dry mass (Fig. 2a; $\mathrm{r}^{2}=0.45, \mathrm{p}<0.0001, \mathrm{n}=151$ ). A power function best described this relation. The inflection point where the slope = 1 was $144 \mathrm{~g}$ lean dry mass and $33 \mathrm{~g}$ dry lipid mass, which corresponds to a wet body mass value just greater than $500 \mathrm{~g}$ (6.6\% adiposity: dry lipid mass divided by wet body mass $\times 100$; Fig. 2a). Below $425 \mathrm{~g}$ wet body mass, lipids were almost completely exhausted and most change was due to a reduction in lean dry mass. In contrast, above $600 \mathrm{~g}$ wet body mass, the change in lipid mass accounted for most (ca 70\%) of the change in body mass.

An exponential fit best described the relation between dry lipid mass and wet pectoralis mass $\left(\mathrm{r}^{2}=0.45\right.$, $\mathrm{p}<0.0001, \mathrm{n}=126$; Fig. 2b). For values greater than $55 \mathrm{~g}$ pectoralis mass, most of the decrease in body mass was attributed to lipid loss. For pectoralis mass less than $45 \mathrm{~g}$, most of the body mass decrease was associated with loss of the breast muscle. This relation implies that mainly lipids were metabolized as shearwaters initially lost body mass, whereas flight muscle mass was mobilized as an energy source once lipid stores were depleted.

A power curve best described the relation between liver mass and liver-free wet body mass $\left(r^{2}=0.43\right.$, $\mathrm{p}<0.0001, \mathrm{n}=191$; Fig. $2 \mathrm{c}$ ), although this relation was almost linear $\left(r^{2}=0.38, \mathrm{p}<0.0001, \mathrm{n}=191\right)$.

\section{Comparisons of body condition among seasons}

Dry lipid mass did not covary significantly with total length $\left(r^{2}=0.005, p=0.39, n=142\right)$, and because variances were unequal among groups, a non-parametric Kruskall-Wallis rank test was performed to test for significant differences in lipid content among seasons. The mean lipid content of short-tailed shearwaters differed among different seasons $(H=73.23, \mathrm{p}<0.0001$, $\mathrm{n}=151$ ). The season with the greatest mean body lipid content was spring 1997 (mean = $94.73 \mathrm{~g}$ ) and the lowest values (mean $=3.23 \mathrm{~g}$ ) were among beachcast birds collected during the die-off in August 1997 (Fig. 3). Interestingly, mean lipid values were lower during fall 1998 $($ mean $=31.05 \mathrm{~g})$ than fall 1997 (mean $=45.59)$, yet no die-off occurred. The lipid content of beachcast birds was essentially exhausted $(<5 \mathrm{~g})$, indicating that they had consumed their lipid energy reserves.

Pectoralis mass covaried significantly with total length ( $F=16.53, \mathrm{p}<0.0001, \mathrm{n}=236)$ and there were significant differences among seasons in adjusted mean pectoralis mass ( $F=16.49, \mathrm{p}<0.0001, \mathrm{n}=236$; Fig. 3$)$. Liver mass did not covary significantly with total length and variances among seasons were unequal. A KruskallWallis test showed that there were significant differences in mean liver mass among seasons $(H=39.80, \mathrm{p}<$ $0.001, \mathrm{n}=191$ ). Mean liver mass of beachcast birds collected during the 1997 die-off were significantly lower than mean liver mass of birds in spring and fall 1998 and 1999 (liver mass was not collected in spring and fall 1997; Fig. 3). 

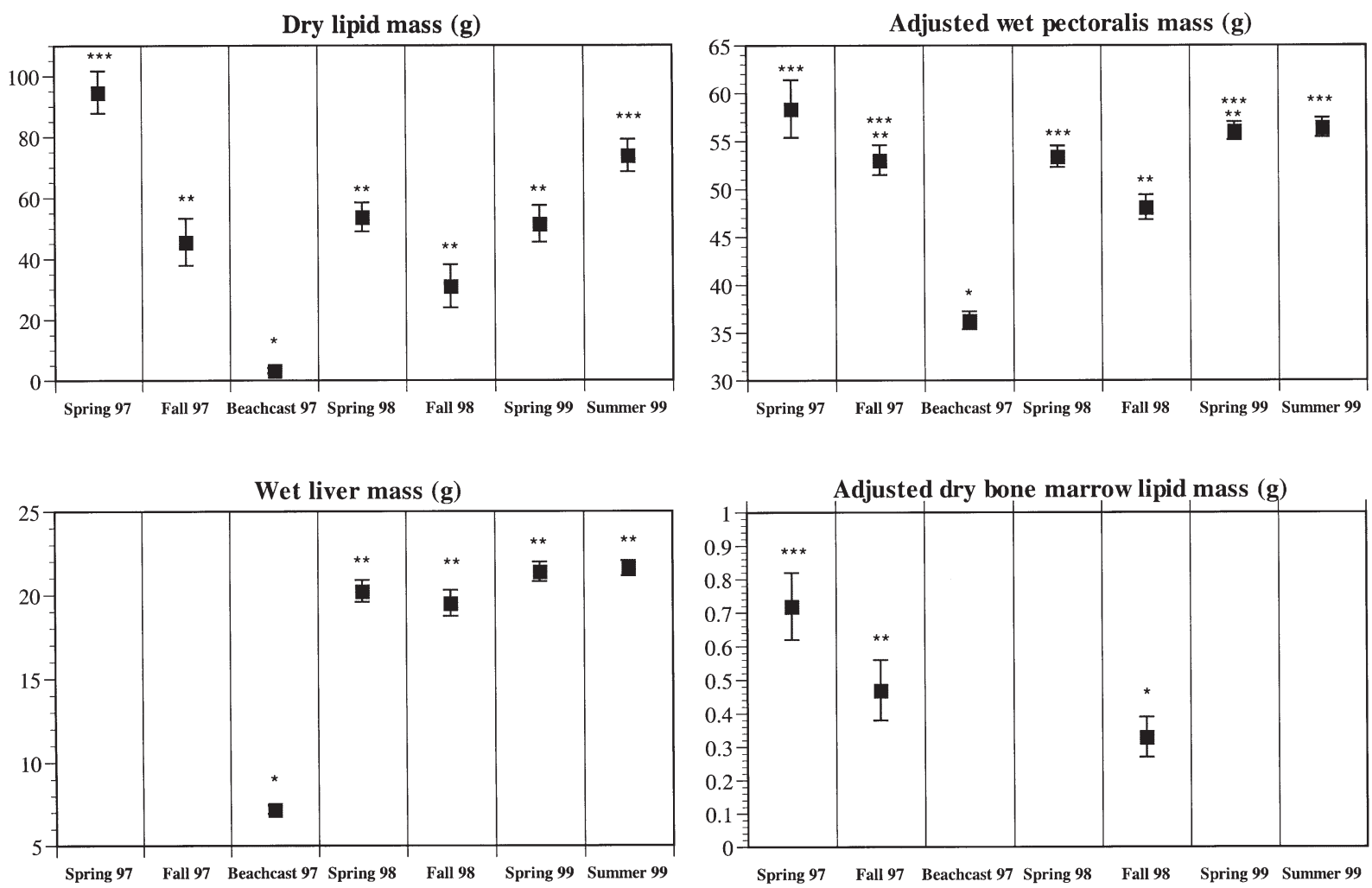

Fig. 3. Seasonal differences in dry lipid mass, wet pectoralis mass, wet liver mass, and dry bone marrow lipid mass. Means were adjusted when covariate (total length) was significant. Means \pm SE reported for each season. Seasons that are significantly different from one another $(\mathrm{p}<0.05)$ are marked by different asterisk patterns $\left({ }^{*},{ }^{* *},{ }^{*}\right.$ or $\left.{ }^{* * *}\right)$. Seasons that are statistically indistinguishable are marked by similar asterisk patterns

The lipid content of leg bone marrow covaried significantly with total length $(F=4.77, \mathrm{p}=0.037, \mathrm{n}=33)$ but not with tarsus length or tarsus mass, and thus bone lipid content was adjusted for body size. There were significant differences among the adjusted mean bone marrow lipid content in spring 1997, and in fall, during the die-off (Tukey multiple comparison, $\mathrm{p}=0.031, \mathrm{n}=26$; Fig. 3), spring 1997 and fall 1998 (Tukey, $\mathrm{p}=0.045, \mathrm{n}=18$; Fig. 3). Bone marrow lipid content was lower during the die-off in fall 1997 (adjusted mean $=0.470 \mathrm{~g}$ ) than during the previous spring 1997 (adjusted mean $=0.720 \mathrm{~g}$ ). However, the bone marrow lipid content was significantly lower in fall 1998 (adjusted mean $=0.330 \mathrm{~g}$ ) than that in birds during the die-off in fall 1997. Most birds collected during the die-off had a measurable amount of lipid left in the bone marrow (mean \pm SE: $0.47 \pm 0.09 \mathrm{~g}$ ), indicating that marrow lipid stores were still available as an energy source.

\section{Estimation of flight ranges}

Flight ranges for short-tailed shearwaters that were in poor body condition and close to death (wet body mass $426 \mathrm{~g}$ ) and in which lipids were nearly exhausted
$(11 \mathrm{~g})$ were 137 to $548 \mathrm{~km}$ (Table 3). The flight ranges for birds weighing $500 \mathrm{~g}$, the body mass at which the change in lipids equaled the change in lean dry mass, were 959 to $3836 \mathrm{~km}$. For birds foraging for offspring at a colony in Tasmania, flight ranges were 2000 to $8500 \mathrm{~km}$ based on fat stores (59 to $72 \mathrm{~g}$ ) estimated from published body masses. Shearwaters leaving colonies in southeast Australia and migrating to the North Pacific Ocean with ca $67 \mathrm{~g}$ of body fat had maximum range estimates of $8320 \mathrm{~km}$. Thus, shearwaters must encounter adequate densities of prey within 2000 to $8000 \mathrm{~km}$ of leaving the colony before body condition deteriorates and starvation is possible.

\section{DISCUSSION}

\section{Changes in body composition with starvation}

The anomalous weather events that occurred in the southeastern Bering Sea during 1997 to 1999 (Vance et al. 1998) and the shearwater mortality event that resulted in July to September 1997 (Baduini et al. in press) allowed us to observe changes in body composi- 


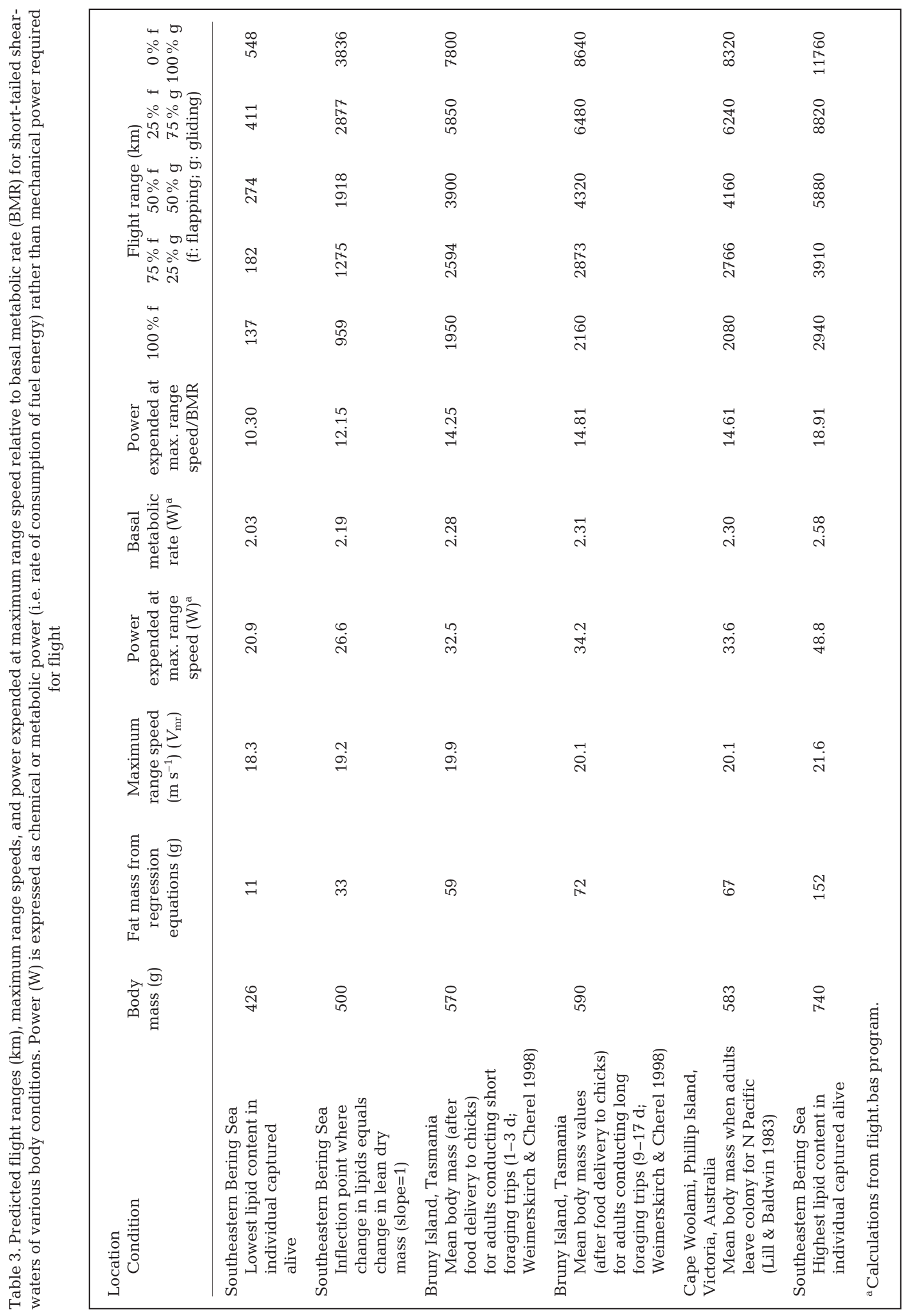


tion of shearwaters during starvation. The changes in body composition in an undernourished wild population of short-tailed shearwaters were consistent with other models in which birds and mammals were experimentally fasted in a controlled environment (Cherel \& Le Maho 1985, Cherel et al. 1987, Robin et al. 1988). Birds and mammals adjust to long-term fasting and starvation by increasing fat utilization and sparing protein (Cherel et al. 1988, Robin et al. 1988, Groscolas et al. 1991, Cherel et al. 1993, Cherel et al. 1995, Cherel \& Groscolas 1999).

Three metabolic phases have been characterized during long-term fasting and starvation in penguins and domestic geese (Cherel et al. 1988). In Phase I, during the first few days without food, there is a sharp decrease in daily mass loss along with a decrease in protein catabolism. Phase II is characterized by utilization of neutral lipid stores, protein sparing, and a decrease in the rate of mass loss. During Phase III, there are low amounts of lipids left, protein is no longer spared and catabolism occurs, and the rate of mass loss increases. Protein catabolism increases during Phase III before lipid stores are completely depleted and is reversible (Cherel et al. 1988, Cherel \& Le Maho 1991, Robin et al. 1998).

During starvation, short-tailed shearwaters initially lost lipid mass at a greater rate than muscle mass. There was a measurable amount of pectoralis muscle left in all of the birds collected. Because the decrease in pectoralis muscle mass was more gradual than lipid loss, and muscle loss did not increase until lipid mass values were below $20 \mathrm{~g}$ (Fig. 2b), proteins were selectively spared as body mass decreased and individuals starved. Although birds that have been recorded starving in the wild usually have reduced and atrophied pectoralis muscles (Piersma 1988), the use of these muscles and the ability to fly must be one of the last faculties to fail with the onset of starvation. The loss of the use of these muscles and inability to fly essentially inhibits a bird's ability to find prey, especially in species that must locate widely dispersed, patchy, and unpredictable food supplies, as in most seabirds.

Lipids were used mostly as an energy source until body mass decreased to about $500 \mathrm{~g}$. Below $500 \mathrm{~g}$, there was greater use of lean dry mass as an energy source. Bone marrow lipids, one of the last lipid stores to be used during starvation, had been mobilized by birds in fall 1997 and 1998. Coincidentally, in fall of 1997 and 1998, mean body mass values were $515 \pm 9 \mathrm{~g}$ and $498 \pm 14 \mathrm{~g}$, respectively, and bone marrow lipids were significantly lower than in spring 1997, indicating that one of the last lipid stores utilized was being depleted. Approximately $500 \mathrm{~g}$ may be the lower limit of body mass at which short-tailed shearwaters enter Phase III of starvation. Although shearwaters were captured alive at body mass $426 \mathrm{~g}$, birds began to die when approaching this mass, as evidenced by the beachcast carcass data in which birds weighed $480 \mathrm{~g}$ or less $($ mean $=380 \mathrm{~g})$. Nevertheless, beachcast birds died during or after Phase III of starvation. A body mass of $450 \mathrm{~g}$ may be a more biologically relevant valve for determining the onset of starvation and the increased probability of death. The energy expenditure of a bird sitting on the water and preening is approximately 1.2 times BMR (Dolnik 1980). Given this energy expenditure of birds that can no longer fly or are unwilling to fly in calm wind conditions, a shorttailed shearwater weighing 400 to $450 \mathrm{~g}$ can probably survive no more than 1 to $2 \mathrm{~d}$ before starving to death.

\section{Comparisons of body condition among seasons}

Mean lipid values for spring and fall 1998 were lower than those of shearwaters collected alive during the die-off in September 1997. It is somewhat puzzling why shearwaters collected in 1998 had lower lipid and lower pectoralis mass values, yet no large-scale mortality event was observed. There are 2 possible explanations why short-tailed shearwaters may have starved and died in 1997 but not in 1998. One is that winds were relatively absent throughout summer 1997 compared with 1998; thus, the increased flight costs in 1997 may have contributed to the demise of shorttailed shearwaters.

Shearwaters require moderate wind speeds (8 to $12 \mathrm{~m} \mathrm{~s}^{-1}$ ) for efficient gliding flight (Alerstam et al. 1993). Daily wind speeds from the ship's logs indicated that during the die-off in fall 1997, less than $50 \%$ of days had wind speeds averaging $>8 \mathrm{~m} \mathrm{~s}^{-1}$. During the same time in fall 1998, $70 \%$ of days had wind speeds averaging $>8 \mathrm{~m} \mathrm{~s}^{-1}$ (C. Baduini pers. obs.). The greater number of windy days in fall 1998 probably reduced the energy costs of flight for shearwaters. Without wind, shearwaters are required to fly by flapping rather than soaring. Costs for flapping flight have been estimated to be 6 to 8 times greater than soaring flight, depending on flight speed (Alerstam et al. 1993). This dramatic change in costs of flight may have helped short-tailed shearwaters escape another large-scale mortality event in 1998 if they were able to fly by soaring more often than in 1997.

A second explanation is that an alternative prey resource was available during fall 1998 that was not available in 1997 (C. Baduini pers. obs.). Shearwaters were observed foraging on juvenile (age-0 class) walleye pollock Theragra chalcogramma in the area of the middle southeastern Bering Sea shelf, southwest of Cape Newenham, in 1998 and not in 1997. Usually, the diet of short-tailed shearwaters in the southeastern 
Bering Sea is dominated by adult euphausiids, primarily Thysanoessa raschii (Hunt et al. 1996, Ogi 1980). A lack of euphausiids in nearshore surface waters or a shift in their horizontal and vertical distribution in 1997 may have made it difficult for short-tailed shearwaters to obtain sufficient resources (Baduini et al. 2001). In 1997 and 1998 a shift was observed in the diet of shorttailed shearwaters from primarily a euphausiid diet in spring, to an almost complete diet of fish, juvenile pollock, and sandlance Ammodytes hexapterus (Hunt et al. in press, C. Baduini pers. obs.). Predominant southwest winds and strong cross-shelf transport in water currents transported a substantial portion of the 1998 year class of pollock onto the Bering Sea shelf in August and September, and short-tailed shearwaters then foraged on them. It is possible that the availability of this prey resource sustained short-tailed shearwaters and prevented them from dying.

\section{Estimation of flight ranges}

Adaptive body mass loss and lipid levels have major implications for the amount of energy reserves shorttailed shearwaters can carry on board, for flight costs, and for distances that individuals can fly in search of food. Lower lipid levels limit travel distances between or among prey patches, and in the case of migration, limit the distances that can be traveled between major centers of ocean productivity. Short-tailed shearwaters migrate in waves of very large flock sizes (thousands to tens of thousands) and may occasionally stop to feed along the way. However, feeding conditions are unlikely to be consistent enough over areas of lower productivity to supply significant replenishment of reserves.

According to the estimated flight ranges, shearwaters weighing less than $500 \mathrm{~g}$ in fall 1997 and $1998 \mathrm{did}$ not have enough lipid stores to complete a migratory flight out of the Bering Sea without refueling. Individuals weighing less than $426 \mathrm{~g}$, with a maximum estimated flight range of $548 \mathrm{~km}$ (Table 3), were likely to starve unless they encountered prey aggregations where stores could be replenished. Short-tailed shearwaters have been estimated to travel from 600 to $1124 \mathrm{~km} \mathrm{~d}^{-1}$ while searching for prey and feeding in antarctic waters (Nicholls et al. 1998, Klomp \& Schultz 2000). Our estimated range estimates indicate that birds in poor condition (<500 $\mathrm{g}$ body mass) in the southeastern Bering Sea were probably starving and close to death. Shearwaters captured alive in late summer 1999 weighed $570 \mathrm{~g}$, on average, and had estimated flight ranges from 1950 to $7800 \mathrm{~km}$. These birds could sustain flight between substantive prey aggregations while moving out of the Bering Sea and across the North Pacific Ocean.
The level of energetic stores also has implications for migration routes and the occurrence of starvation events. Upon leaving the colony at Cape Woolami in southeast Australia, adult short-tailed shearwaters have minimum flight ranges of $2080 \mathrm{~km}$ and maximum ranges of $8320 \mathrm{~km}$ (Table 3). Although the exact migration route is unknown and has been a topic of speculation for some time, it has been proposed that when short-tailed shearwaters are headed toward wintering grounds in the northern hemisphere, they migrate northward along the western side of the North Pacific Ocean toward Japanese waters, where the number of birds is greatest during April through June (Ogi et al. 1980, Oka \& Maruyama 1986, Watabe et al. 1987, Minami et al. 1995). From Japanese waters, short-tailed shearwaters move toward the Bering and Chukchi Seas, where they spend the months of May though October feeding. At least 1 possible return route occurs along the coasts of Canada and northwestern United States, in the California Current region, where short-tailed shearwater sightings are greatest from September through January (Baltz \& Morejohn 1977). There are few birds in Japanese waters from September to November, the prospected time when short-tailed shearwaters are headed southward during their return to breeding colonies (Watabe et al. 1987). A more direct route has been proposed in which shearwaters move northward in broad fronts directly toward the Northwest Pacific and progress rapidly through the equatorial western Pacific (Shuntov 1974), but there is little evidence (from sighting or net entrapment data) to support this pattern of movement. Upon arrival in the subarctic, birds move into the Sea of Okhotsk, the Bering and Chukchi seas, and the Gulf of Alaska. This migration route takes short-tailed shearwaters over waters of relatively low productivity in the subtropical and tropical equatorial zone. Data from a Coastal Zone Color Scanner composite image from 1978 to 1981, which projected changes in seawater color with changing concentrations of photosynthetic pigment and ocean productivity, showed that the shortest linear distance from Tasmania to productive waters was to the waters off Japan (courtesy of J. A. Elrod and G. C. Feldman, NASA/Goddard Space Flight Centre; data not shown). Also, there is a region just east of the Marshall Islands in the equatorial Pacific that has elevated photosynthetic production levels. The great circle route from southeast Australia to Japan is approximately $8700 \mathrm{~km}$ and from Tasmania to Japan is approximately $9300 \mathrm{~km}$. If large groups of shorttailed shearwaters migrating from southeast Australia and Tasmania toward Japan do not encounter large aggregations of prey en route or shortly after they arrive, starvation events may occur because 
exhausted lipid stores cannot be replenished upon arrival.

The body condition and thus energetic stores of parent short-tailed shearwaters influences the foraging strategy taken by parents when provisioning for offspring at the colony. Weimerskirch \& Cherel (1998) described the alternation of long ( 9 to $17 \mathrm{~d}$ ) and short ( 1 to $3 \mathrm{~d}$ ) foraging trips that occurs when the body condition of adults and chicks fluctuate during the breeding season. Decisions whether to forage in close or distant waters were determined by the body condition of the parent. On average, there was only a $20 \mathrm{~g}(11 \mathrm{~g})$ difference in body (lipid) mass of adults (after feeding chicks) returning from long (590 g) and short (570 g) foraging trips. This amount translated to a difference in flight range of 200 to $400 \mathrm{~km}$ for the 2 kinds of trips. The flight ranges we calculated were consistent with estimated flight ranges in which adults from the breeding colony on Bruny Island were observed to travel to the subantarctic polar front $(1000 \mathrm{~km}$ roundtrip) and to the antarctic polar front $(2400 \mathrm{~km}$ roundtrip) in search of prey (Weimerskirch \& Cherel 1998). Shearwaters in relatively good body condition probably have energetic lipid stores that would support a flight range of $1000 \mathrm{~km} \mathrm{~d}^{-1}$ for up to $1 \mathrm{wk}$. This range would allow individuals time to find distant and less predictable, yet highly aggregated prey patches.

In this paper, we described patterns of lipid, muscle, liver, and bone marrow lipid loss in wild populations of short-tailed shearwaters. These provided us with the opportunity to understand the changes that occur in body composition with nutritional stress. On the basis of this information, we can predict the body condition of a short-tailed shearwater given its body mass and estimate the flight range and time remaining to find dense aggregations of prey from which stores may be replenished. The patterns of changes in body composition described here will be useful in understanding the annual energetic strategies and mortality patterns of short-tailed shearwaters during their long-distance annual movements between oceanic regions with high productivity and seasonal variability of prey resources.

\footnotetext{
Acknowledgements. Thanks to the captain and crew of the RV 'Alpha Helix' for their support and expertise on research cruises, and to the following for their assistance on cruises and in the laboratory: J. Carlson, T. Fotev, B. Gibbons, J. Jahncke, N. Karnovsky, B. M. Myers III, M. Ngo, J. Parga, C. Pickens, H. Revilee, G. Savage, M. Tran, and L. Vlietstra. A. Bennett, T. Bradley, and B. A. Hawkins provided helpful comments that improved the quality of this manuscript. This research was supported by National Science Foundation Office of Polar Programs grant NSF-OPP-9617287 to G.L.H. and by the National Oceanic and Atmospheric Administration, Pacific Marine Environmental Laboratory.
}

\section{LITERATURE CITED}

Akkeson A, Karlsson L, Pettersson J, Walinder G (1992) Body composition and migrating strategies: a comparison between robins (Erithacus rubecula) from two stop-over sites in Sweden. Vogelwarte 36:188-195

Alerstam T, Gudmundsson GA, Larsson B (1993) Flight tracks and speeds Antarctic and Atlantic seabirds: radar and optical measurements. Phil Trans R Soc Lond 340B:55-67

Baduini CL, Hyrenbach KD, Coyle KO, Pinchuk A, Mendenhall V, Hunt GL Jr (2001) Mass mortality of short-tailed shearwaters in the southeastern Bering Sea during summer 1997. Fish Oceanogr 10:117-130

Ballance LT (1995) Flight energetics of free-ranging redfooted boobies (Sula sula). Physiol Zool 68(5):887-914

Baltz DM, Morejohn GV (1977) Food habits and niche overlap of seabirds wintering on Monterey Bay, California. Auk 94:526-543

Chan-McLeod AAC, White RG, Russell DE (1995) Body mass and composition indices for female barren-ground caribou. J Wildl Manage 59:278-291

Cherel Y, Groscolas R (1999) Relationships between nutrient storage and nutrient utilisation in long-term fasting birds and mammals. In: Adams NJ, Slotow RH (eds) Proc 22 Int Ornithol Congr, Durban. BirdLife South Africa, Johannesburg, p 17-34

Cherel Y, Le Maho Y (1985) Five months of fasting in king penguin chicks: body mass loss and fuel metabolism. Am J Physiol 249:R387-R392

Cherel Y, Le Maho Y (1991) Refeeding after the late increase in nitrogen excretion during prolonged fasting in the rat. Physiol Behav 50:345-349

Cherel Y, Stahl JC, Le Maho Y (1987) Ecology and physiology of fasting in king penguin chicks. Auk 104:254-262

Cherel Y, Robin JP, Le Maho Y (1988) Physiology and biochemistry of long-term fasting in birds. Can J Zool 66: 159-166

Cherel Y, Robin JP, Heitz A, Calgari C, Le Maho Y (1992) Relationships between lipid availability and protein utilization during prolonged fasting. J Comp Physiol B 162: 305-313

Cherel Y, Freby F, Gilles J, Robin JP (1993) Comparative fuel metabolism in gentoo and king penguins: adaptation to brief versus prolonged fasting. Polar Biol 13:263-269

Cherel Y, El Omari B, Le Maho Y, Saboureau M (1995) Protein and lipid utilization during fasting with shallow and deep hypothermia in the European hedgehog (Erinaceus europaeus). J Comp Physiol B 164:653-658

Christie WW (1982) Lipid analysis, 2nd edn. Pergamon Press Canada Ltd, Toronto

Davis JL, Valkenburg P, Reed DJ (1987) Correlations and depletion patterns of marrow fat in caribou bones. J Wildl Manage 51:365-371

Dobush GR, Ankney CD, Krementz DG (1985) The effect of apparatus, extraction time, and solvent type on lipid extractions of snow geese. Can J Zool 63:1917-1920

Dolnik VR (1980) Time and energy budgets in free-living birds. Proc Zool Inst 113:2-36

Douglas G, Setton A (1955) Mortality of shearwaters. Emu 55: $259-262$

Fournier MA, Hines JE (1994) Effects of starvation on muscle and organ mass of king eiders Somateria spectabilis and the ecological and management implications. Wildfowl 45:188-197

Furness RW, Bryant DM (1996) Effect of wind on field metabolic rates of breeding northern fulmars. Ecology 77 : 1181-1188 
Gauthier G, Giroux JF, Bedard J (1992) Dynamics of fat and protein reserves during winter and spring migration in greater snow geese. Can J Zool 70:2077-2087

Groscolas R, Schreiber L, Morin F (1991) The use of tritiated water to determine protein and lipid utilization in fasting birds: a validation study in incubation great-winged petrels, Pterodroma macroptera. Physiol Zool 64: 1217-1233

Hunt GL Jr, Gould PJ, Forsell DJ, Peterson H Jr (1981) Pelagic distribution of marine birds in the Eastern Bering Sea. In: Hood DW, Calder JA (eds) The Eastern Bering Sea shelf: oceanography and resources. Office of Marine Pollution Assessment of the National Oceanic and Atmospheric Administration, University of Washington Press, Seattle, p 689-718

Hunt GL Jr, Coyle KO, Hoffman S, Decker MB, Flint EN (1996) Foraging ecology of short-tailed shearwaters near the Pribilof Islands, Bering Sea. Mar Ecol Prog Ser 141: $1-11$

Hunt GL Jr, Baduini CL, Jahncke J (in press) Variation in diet of short-tailed shearwaters in the southeastern Bering Sea. Deep-Sea Res Part II

Hutchinson AE, Owen RB (1984) Bone marrow fat in waterfowl. J Wildl Manage 48:585-591

Jenni L, Jenni-Eiermann S (1999) Fat and protein utilisation during migratory flight. In Adams NJ, Slotow RH (eds) Proc 22nd Int Ornithol Congr, Durban. BirdLife South Africa, Johannesburg, p 1437-1449

Jenni-Eiermann S, Jenni L (1991) Metabolic responses to flight and fasting in night migrating passerines. J Comp Physiol B161:465-474

Jenni-Eiermann S, Schifferli L (1989) Body composition of starved tufted ducks Aythya fuligula, pocahrds A. ferina and little grebes Tachybaptus ruficollis. Wildfowl 40:99-105

Jeske CW, Szymczak MR, Anderson DR, Ringleman JK, Armstrong JA (1994) Relationship of body condition to survival of mallards in San Luis Valley, Colorado. J Wildl Manage 58:787-793

Kawaguchi K, Marumo R (1964) Mass mortality of slenderbilled shearwaters, Puffinus tenuirostris, in Suruga Bay. Misc Rep Yamashina Inst Ornithol 14:106-113

Kerr DC, Ankney CD, Millar JS (1982) The effect of drying temperature on extraction of petroleum ether soluble facts of small birds and manuals. Can J Zool 60:470-472

Klomp NI, Schultz MA (2000) Short-tailed shearwaters breeding in Australia forage in Antarctic waters. Mar Ecol Prog Ser 194:307-310

Kuroda N (1967) A note on the mass mortality of Puffinus tenuirostris in Miyazaki, Kyushu. Tori 18:198-199 (in Japanese with English summary)

La Jeunesse TA, Peterson RO (1993) Marrow and kidney fat as condition indices in gray wolves. Wildl Soc Bull 21: 87-90

Lill A, Baldwin J (1983) Weight changes and the mode of depot fat accumulation in migratory short-tailed shearwaters. Aust J Zool 31:891-902

Lindstrom A, Piersma T (1993) Mass changes in migrating birds: the evidence for fat and protein storage re-examined. Ibis 135:70-78

Little K (1973) Bone behaviour. Academic Press, London

Lovvorn JR (1994) Nutrient reserves, probability of cold spells and the question of reserve regulation in wintering canvasbacks. J Anim Ecol 63:11-23

Minami H, Minagawa M, Ogi H (1995) Changes in stable carbon and nitrogen isotope ratios in sooty and short-tailed shearwaters during their northward migration. Condor 97: 565-574
McRoy CP, Hood DW, Coachman LK, Walsh JJ, Goering JJ (1986) Processes and resources of the Bering Sea shelf (PROBES): the development and accomplishments of the project. Cont Shelf Res 5:5-21

Nicholls DG, Stampton P, Klomp NI, Schultz M (1998) Postbreeding flight to Antarctic waters by a short-tailed shearwater Puffinus tenuirostris. Emu 98:79-82

Ogi H, Kubodera T, Nakamura K (1980) The pelagic feeding ecology of the short-tailed shearwater Puffinus tenuirostris in the subarctic Pacific region. J Yamashina Inst Ornithol 12:19-44 (in English)

Oka N, Maruyama N (1985) Visual evaluation of tibiotarsus and femur marrows as a method of estimating nutritive conditions of short-tailed shearwaters. J Yamashina Inst Ornithol 17:57-65

Oka N, Maruyama N (1986) Mass mortality of short-tailed shearwaters along the Japanese coast. Tori 34:97-104

Owen N, Cook WA (1977) Variations in body weight, wing length and condition of mallard Anas platyrhynchos platyrhynchos and their relationship to environmental changes. J Zool 183:377-395

Ozawa K (1964) Records and observations of an unusual wreck of slender-billed shearwaters on the Pacific coast of Japan, end of May, 1964. Misc Rep Yamashina Inst Ornithol 4:114-117

Packard GC, Boardman TJ (1987) The misuse of ratios to scale physiological data that vary allometrically with body size. In: Feder ME, Bennett AF, Burggren WW, Huey RB (eds) New directions in ecological physiology. Cambridge University Press, Cambridge, p 216-239

Pennycuick CJ (1989) Bird flight performance: a practical calculation manual. Oxford University Press, New York. Software available at: http://nhsbig.inhs.uiuc.edu/wes/ pennycuick.html

Piersma T (1988) Breast muscle atrophy and constraints on foraging during the flightless period of wing molting great crested grebes. Ardea 76:96-106

Piersma T, Jukema J (1990) Budgeting the flight of a longdistance migrant: changes in nutrient reserve levels of bar-tailed godwits at successive spring staging sites. Ardea 78:315-337

Pond CM (1978) Morphological aspects and the ecological and mechanical consequences of fat deposition in wild vertebrates. Annu Rev Ecol Syst 9:519-570

Raveling DG, Sifri M, Knudsen RB (1978) Seasonal variation of femur and tibiotarsus constituents in Canada geese. Condor 80:246-248

Robin JP, Frain M, Sardet C, Groscolas R, Le Maho,Y (1988) Protein and lipid utilization during long-term fasting in emperor penguins. Am J Physiol 254:R61-R68

Robin J, Boucontet L, Chillet P, Groscolas R (1998) Behavioral changes in fasting emperor penguins: evidence for a 'refeeding signal' linked to a metabolic shift. Am J Physiol 274:R746-R753

Roby DD (1991) A comparison of two noninvasive techniques to measure total body lipid in live birds. Auk 108:509-518

Serventy DL (1958) Recent studies on the Tasmanian muttonbird. Aust Mus Mag 12:327-332

Serventy DL (1967) Aspects of the population ecology of the short-tailed shearwater, Puffinus tenuirostris. Proc 14th Int Orn Congr, Oxford, p 165-190

Shuntov VP (1974) Seabirds and the biological structure of the ocean. Serial No TT-74-55032. National Technical Information Service, US Department of Commerce, Springfield (translated from Russian)

Skira IJ (1986) Food of the short-tailed shearwater, Puffinus tenuirostris, in Tasmania. Aust Wildl Res 13:481-488 
Sugimori F, Oka N, Iwase Y (1976) A questionnaire survey of shearwater mortality, especially of Puffinus tenuirostris. Rep Yamashina Inst Ornithol 8:113-131 (in Japanese with English summary)

Tatner P, Bryant DM (1989) Doubly-labeled water technique for measuring energy expenditure. In: Bridges CR, Butler PJ (eds) Techniques in comparative respiratory physiology: an experimental approach. Cambridge University Press, Cambridge, p 77-112

Thouzeau C, Massemin S, Handrich Y (1997) Bone marrow fat mobilization in relation to lipid and protein catabolism during prolonged fasting in barn owls. J Comp Physiol B 167:17-24

Vance TC, Schumacher JD, Stabeno PJ, Baier CT and 11 others (1998) Aquamarine waters recorded for the first time in

Editorial responsibility: Otto Kinne (Editor),

Oldendorf/Luhe, Germany the eastern Bering Sea. EOS Trans Am Geophys Union 79: 121,126

van der Meer J, Piersma T (1994) Physiologically inspired regression models for estimating and predicting nutrient stores and their composition in birds. Physiol Zool 67: 305-329

Warham J (1990) The petrels: their ecology and breeding systems. Academic Press, London

Watabe Y, Oka N, Maruyama N (1987) Seasonal appearances of short-tailed shearwaters (Puffinus tenuirostris) and sooty (Puffinus griseus) shearwaters on the Tokyo-Kushiro line, Japan. J Yamashina Inst Ornithol 19:117-124

Weimerskirch H, Cherel Y (1998) Feeding ecology of shorttailed shearwaters: breeding in Tasmania and foraging in the Antarctic? Mar Ecol Prog Ser 167:261-274

Submitted: June 14, 2000; Accepted: March 29, 2001

Proofs received from author(s): October 23, 2001 